\title{
Protein requirement of young adult Nigerian females on habitual Nigerian diet at the usual level of energy intake
}

\author{
BY GLORIA N. EGUN* AND TOLA ATINMO \\ Department of Human Nutrition, College of Medicine, University of Ibadan, Nigeria
}

(Received 12 August 1991-Accepted 14 October 1992)

\begin{abstract}
A short-term $\mathrm{N}$ balance study was conducted in twelve healthy female adults aged 21-32 years to determine their protein requirement. Four dietary protein levels $(0.3,0.4,0.5$ and $0.6 \mathrm{~g}$ protein $/ \mathrm{kg}$ per $\mathrm{d})$ were used. Energy intake of the subjects was kept constant at $0.18 \mathrm{MJ} / \mathrm{kg}$ per d. All subjects maintained their normal activity throughout the study period. $N$ excretion was determined from the measurements of $\mathbf{N}$ in a total collection of urine, faeces, sweat and menstrual fluid for each dietary period. $\mathbf{N}$ balance during the four protein levels were -15.15 (SD 5.95), -5.53 (SD 6.71), +6.15 (SD 4.76) and +12.05 (SD 8.63) $\mathrm{mg} \mathrm{N} / \mathrm{kg}$ per $\mathrm{d}$ for $0.3,0.4,0.5$ and $0.6 \mathrm{~g}$ protein/ $\mathrm{kg}$ per $\mathrm{d}$ respectively. The calculated average $\mathrm{N}$ requirements from regression analysis was 76.0 (SD 3.37$) \mathrm{mg} \mathrm{N} / \mathrm{kg}$ per $\mathrm{d}(0.48 \mathrm{~g}$ protein $/ \mathrm{kg}$ per d). The estimate of allowance for individual variation to cover the $97.5 \%$ population was $95 \mathrm{mg} \mathrm{N} / \mathrm{kg}$ per d $(0.6 \mathrm{~g}$ protein $/ \mathrm{kg}$ per $\mathrm{d})$. The net protein utilization (NPU) of the diet was 0.55 . When compared with a similar study with men, there was a significant difference in the protein requirement between sexes. Thus, the unjustifiable sex difference in the protein allowance recommended by the Food and Agriculture Organization/World Health Organization/United Nations University (1985) Expert Consultation group must be reviewed.
\end{abstract}

Protein requirements: Nitrogen balance: Nigerian diet

There have been various reports of studies on human protein requirements for over a century (Munro, 1985) but the area is still under active investigation as new concepts and more information become available especially from developing countries. More recently attention has focused on protein requirements under conditions prevailing in developing countries where there are cultural, environmental, as well as dietary differences from developed or industrialized countries (United Nations University World Hunger Programme, 1979; Food and Agriculture Organization/World Health Organization/ United Nations University (FAO/WHO/UNU), 1985.

The database from developing countries for setting recommended allowances for protein is increasing but, still, they are mostly based on studies of adult males. There is less extensive information available for adult females. The recent FAO/WHO/UNU (1985) Consultative Group had to depend on the conclusion of the Food and Agriculture Organization/World Health Organization (1973) Expert Group, for values for the obligatory $\mathrm{N}$ losses of women (Bodwell et al. 1979) and results of Calloway \& Kurzer (1982) based on $\mathrm{N}$ balance studies. The conclusion was reached that there was no justification for making a distinction between adult males and females when setting a safe intake of protein. Accordingly, the safe intake of good-quality, highly digestible protein was set at $0.75 \mathrm{~g} / \mathrm{kg}$ per $\mathrm{d}$ for both sexes. There is the need to have more information on women so as to provide more material for future consultative groups on protein requirements.

\footnotetext{
* Present address: Department of Biochemistry, Lagos State University, Badagry Expressway, Lagos, Nigeria.
} 
Our previous attempts at estimating protein requirements for adults in Nigeria (Atinmo et al. 1985, 1988a, b) have been based on young men. The present study set out to investigate the requirement of protein in Nigerian women under prevailing environmental conditions. Although the short-term $\mathrm{N}$ balance technique has been criticized (Millward et al. 1989), it provides valuable information for further investigation (the long-term $\mathrm{N}$ balance evaluation).

\section{MATERIALS AND METHODS}

\section{Subjects}

Twelve young adult females whose ages ranged between 21 and 32 years were the subjects of the present study. They were students of the University of Ibadan who were judged healthy from physical examination and routine laboratory tests. No medication was taken and all subjects remained essentially healthy throughout the study period. Their characteristics are summarized in Table 1. They maintained their normal activity, which included their full academic schedule, and were free living but consumed their food under supervision.

Daily body weights were recorded at 07.00 hours throughout the entire study period under standardized conditions (preprandial, post voiding and with light indoor clothing). The protocol was approved by the Ethical Committee of the College of Medicine and subjects were required to sign consent forms.

\section{Diet and experimental protocol}

The diet was standardized based on foods habitually consumed from a combination of root-tubers, cereals, vegetables and animal products. Orange-flavoured drinks providing $0.5 \mathrm{MJ} /$ bottle were included to raise the energy level of the diet. Complete mineral and vitamin supplements were added to prevent any deficiencies. Components of the habitual diet of the subjects are shown in Table 2.

To determine the level of energy intake a preliminary study on the subjects was carried out for 2 weeks. Daily body weights of the subjects were taken and subjects kept a diary record of their food intakes and daily activities. The estimation of the energy required was determined based on basal metabolic rate (BMR) which was calculated from predictive equations (FAO/WHO/UNU, 1985). The energy intake was then fixed at $0 \cdot 18 \mathrm{MJ} / \mathrm{kg}$ per d, which is about $1.75 \times$ BMR (estimated).

Four dietary protein levels were used for the study: $0 \cdot 3,0.4,0.5$ and $0.6 \mathrm{~g} / \mathrm{kg}$ per d. All subjects were tested on the four graded levels of protein. The subjects were divided into two groups. One group was assigned to an ascending sequence of dietary protein levels and was designated group A. The other group, designated group D, had a descending sequence of dietary protein levels. Each dietary level was preceded by $1 \mathrm{~d}$ on a practically protein-free diet (Atinmo et al. 1985) to enhance adaptation, followed by $10 \mathrm{~d}$ on the test protein. A break of $3 \mathrm{~d}$ between the different protein levels was allowed.

Vegetable-protein intake was maintained constant and changes in protein level were obtained by decreasing and increasing the beef content of the diet. Thus, the animal-protein content of the diet ranged between 120 and $580 \mathrm{~g} / \mathrm{kg}$. Meals were consumed in a pattern the subjects were accustomed to, at $07.00-08.00,13.00-14.00$ and $19.00-20.00$ hours under supervision of the dietitian.

\section{Samples and analyses}

Urine samples were collected throughout on a $24 \mathrm{~h}$ basis in 2 litre plastic bottles, each containing $10 \mathrm{ml} 1 \mathrm{M}-\mathrm{HCl}$. After measuring volume, a portion of each urine sample was frozen for later analyses including total $\mathrm{N}$, creatinine and urea-N.

Faecal samples were collected with the aid of a faecal marker (carmine) as $5 \mathrm{~d}$ pools in 
Table 1. Characteristics of twelve young Nigerian women who participated in the study

\begin{tabular}{|c|c|c|c|c|c|}
\hline Subject & $\begin{array}{c}\text { Age } \\
\text { (years) }\end{array}$ & $\begin{array}{l}\text { Height } \\
\text { (m) }\end{array}$ & $\begin{array}{l}\text { Body wt } \\
(\mathrm{kg})\end{array}$ & $\begin{array}{c}\mathrm{BMR}^{*} \\
(\mathrm{MJ} / \mathrm{d})\end{array}$ & $\begin{array}{c}\text { BMI } \\
\left(\mathrm{kg} / \mathrm{m}^{2}\right)\end{array}$ \\
\hline$A_{04}$ & 23 & 1.55 & $45 \cdot 0$ & 4.86 & $18 \cdot 7$ \\
\hline $\mathrm{A}_{05}$ & 22 & 1.67 & 57.0 & $5 \cdot 60$ & $20 \cdot 4$ \\
\hline$A_{08}$ & 25 & 1.57 & $49 \cdot 0$ & $5 \cdot 10$ & 19.9 \\
\hline$A_{09}$ & 32 & 1.65 & $55 \cdot 0$ & 6.63 & $20 \cdot 2$ \\
\hline$A_{10}$ & 24 & $1 \cdot 56$ & $50 \cdot 0$ & $5 \cdot 17$ & $20 \cdot 5$ \\
\hline$D_{01}$ & 26 & 1.69 & 63.0 & 5.98 & $22 \cdot 1$ \\
\hline$D_{03}^{01}$ & 24 & 1.66 & 57.0 & $5 \cdot 60$ & $20 \cdot 7$ \\
\hline$D_{04}^{03}$ & 21 & 1.61 & 48.0 & 5.04 & 18.5 \\
\hline$D_{05}^{04}$ & 20 & 1.68 & 61.0 & 5.84 & 21.6 \\
\hline$D_{06}^{05}$ & 23 & 1.66 & $49 \cdot 0$ & $5 \cdot 10$ & 17.8 \\
\hline$D_{08}^{06}$ & 23 & 1.71 & $50 \cdot 0$ & $5 \cdot 17$ & $17 \cdot 1$ \\
\hline$D_{11}^{08}$ & 25 & 1.55 & 53.0 & $5 \cdot 36$ & $22 \cdot 1$ \\
\hline Mean & $24 \cdot 0$ & 1.63 & $53 \cdot 1$ & $5 \cdot 45$ & 20.0 \\
\hline SD & 30 & 0.06 & $5 \cdot 5$ & 0.50 & \\
\hline
\end{tabular}

BMR, basal metabolic rate; BMI, body mass index weight $/$ height $^{2}$.

* Calculated by the Food and Agriculture Organization/World Health Organization (1973) method.

Table 2. Composition $(\mathrm{g} / \mathrm{d})$ of the experimental Nigerian diet

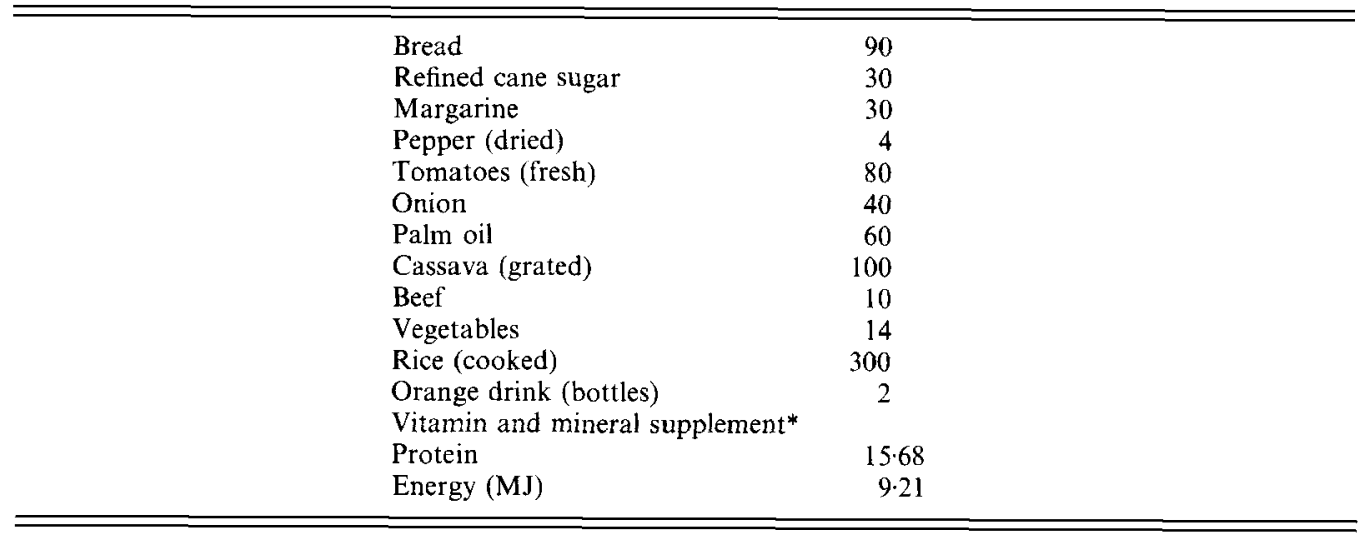

* Vitamin and mineral supplement was provided in the form of a capsule prepared by Ricker Laboratories, Loughborough, UK and containing $(\mathrm{mg})$ : retinoic acetate $5.000 \mu \mathrm{g}$, pyridoxine $100.0 \mu \mathrm{g}$, thiamin 2.25 , cyanocobalamin $2.0 \mu \mathrm{g}$, riboflavin $2 \cdot 25$, ascorbic acid 40 , pantothenic acid 0.5 , cholecalciferol $300 \mu \mathrm{g}, \alpha$-tocopheryl acetate $2 \cdot 0$, copper sulphate $2 \cdot 95$, nicotinamide 20.0 , manganese sulphate 4.0 , dried ferrous sulphate 51.0 , potassium chloride $5 \cdot 6$, anhydrous dibasic calcium phosphate $255 \cdot 0$, dried magnesium sulphate $75 \cdot 0$, potassium iodide $0 \cdot 2$, zinc sulphate $4 \cdot 4$.

preweighed plastic containers. Collections were frozen before being homogenized in a blender. Menstrual fluids were collected on sanitary pads and tampons, which were immediately frozen after use. The tampons and pads from each menstrual period per individual were soaked for $24 \mathrm{~h}$ in a measured volume of $0.1 \mathrm{M}-\mathrm{HCl}$ to elute the $\mathrm{N}$. Sweat $\mathrm{N}$ was collected for $2 \mathrm{~d}$ during each balance period on nine of the subjects. The mean value for each period was used in $\mathrm{N}$ balance calculations. The collection method was similar to that described by Sirbu et al. (1967) and Spence et al. (1972).

The $\mathrm{N}$ content of the diets, urine, faeces, sweat and menstrual collections were determined by the microKjeldahl method as modified by Munro \& Fleck (1969). Creatinine 
and urea- $\mathrm{N}$ were determined by the automated method (Technicon Corp., Irvine, CA, USA), modifications of the Jaffe reaction (Bonsnes \& Taussky, 1945) and the carbaminodiacetyl reaction (Wybenga et al. 1971) respectively. Possible changes in body composition were determined by anthropometric measurements at the beginning and end of each dietary period. These measurements included mid-arm circumference, waist circumference and skinfold thickness at the triceps, biceps, subscapular and suprailiac regions.

\section{Data analysis}

$\mathrm{N}$ balance was calculated from $\mathrm{N}$ intake, faecal, urine and miscellaneous losses. The linear regression analysis equation relating $\mathrm{N}$ intake to $\mathrm{N}$ balance was used to estimate individual $\mathrm{N}$ requirements (Rand et al. 1977). The average requirement that can cover $97.5 \%$ of the population studied taking individual variation into consideration was determined. The protein-quality indices, net protein utilization (NPU), biological value (BV) and true and apparent digestibilities, were calculated by the conventional method (United Nations World Hunger Programme, 1979).

Two-way analysis of variance (ANOVA) was used to test for changes in data obtained at the different dietary protein levels. A change is considered significant at $P<0.05$. Conversion of the $\mathrm{N}$ values to protein was done by multiplying by the factor 6.25 . Comparison between sexes was done by the Student's $t$ test.

\section{RESULTS}

\section{Subject characteristics}

Body-weight and anthropometric changes of the subjects are presented in Table 3 . The mean changes were not statistically different. Five subjects maintained stable body weights while weights fluctuated slightly but not significantly in other subjects. Anthropometric changes also varied among subjects. Differences were not statistically significant $(P>0.5)$.

\section{Urinary output}

Table 4 shows the mean values of urinary output for the last $5 \mathrm{~d}$ for each dietary period. Urinary $\mathrm{N}$ was found to increase significantly with increasing protein intake for the group as a whole $(P<0.001)$ and also among individuals $\left(F_{11,33} 3.74, P<0.05\right)$. Urinary urea-N excretion accounted for a larger percentage of the total urinary $\mathrm{N}$ when protein intake was raised. The percentage increased significantly $(P<0 \cdot 001)$ from 53 to about 72 with the $0.3-0.6 \mathrm{~g}$ protein $/ \mathrm{kg}$ per $\mathrm{d}$ intake. Urinary creatinine, which was used to judge the completeness of urine collection, increased slightly but did not change with the level of protein intake $(P>0.05)$.

\section{Nitrogen balance and requirements}

Details of $\mathrm{N}$ balance data are shown in Table 5. Urinary $\mathrm{N}$ was the mean value for the last $5 \mathrm{~d}$ for each dietary level. Faecal $\mathrm{N}$ was the pooled faecal $\mathrm{N}$ for the $5 \mathrm{~d}$ collection period and it did not change significantly with changing protein intake, using two-way ANOVA $\left(F_{3,33} 2.5, P>0.05\right)$. Loss of $\mathrm{N}$ through menstrual flow was found to be 1.5 (SD 0.38$) \mathrm{mg}$ $\mathrm{N} / \mathrm{kg}$ per $\mathrm{d}$ as the mean of all subjects for the entire experimental study period. Loss of $\mathrm{N}$ through the skin (sweat) was found to vary significantly with protein intake; the mean values for nine subjects were 5.45 (SD 0.79), 6.36 (SD 0.70), 6.65 (SD 0.73) and 7.10 (SD 0.87) $\mathrm{mg} \mathrm{N} / \mathrm{kg}$ per $\mathrm{d}$ for $0.3,0.4,0.5$ and $0.6 \mathrm{~g}$ protein intake $/ \mathrm{kg}$ per d respectively. The mean values were used in the calculations of balance at each level respectively.

All subjects showed negative $\mathrm{N}$ balance when dietary protein intake was $0.3 \mathrm{~g}$ protein $/ \mathrm{kg}$ per $\mathrm{d}$ while only one subject was in positive balance at $0.4 \mathrm{~g} / \mathrm{kg}$ per $\mathrm{d}$. When dietary protein was raised to 0.5 and $0.6 \mathrm{~g} / \mathrm{kg}$ per $\mathrm{d}$ all subjects had attained positive $\mathrm{N}$ balance. $\mathrm{N}$ balance 
Table 3. Anthropometric changes in twelve young Nigerian women who participated in the study*

\begin{tabular}{|c|c|c|c|c|c|c|}
\hline Subject & Body wt & $(\mathrm{kg})$ & $\begin{array}{c}\text { Waist } \\
\text { (cm) }\end{array}$ & $\begin{array}{l}\text { Total } \\
\text { skinfold } \\
(\mathrm{mm})\end{array}$ & $\begin{array}{c}\text { Mid-arm } \\
\text { muscle } \\
\text { circumference } \\
(\mathrm{mm})\end{array}$ & $\begin{array}{c}\% \\
\text { Body fat }\end{array}$ \\
\hline \multirow[t]{2}{*}{$A_{04}$} & Initial & 40 & 57.0 & $35 \cdot 0$ & $207 \cdot 4$ & $12 \cdot 81$ \\
\hline & Change & 0 & -0.5 & -0.3 & 0 & -0.11 \\
\hline \multirow{2}{*}{$\mathbf{A}_{05}$} & Initial & $57 \cdot 5$ & $72 \cdot 5$ & $92 \cdot 6$ & $246 \cdot 8$ & 26.97 \\
\hline & Change & +0.5 & -1.0 & 0 & +0.02 & 0 \\
\hline \multirow[t]{2}{*}{$\mathrm{A}_{08}$} & Initial & $49 \cdot 0$ & $67 \cdot 0$ & $69 \cdot 0$ & $240 \cdot 6$ & $22 \cdot 60$ \\
\hline & Change & $+1 \cdot 0$ & +2.5 & +3.6 & $+4 \cdot 2$ & +0.74 \\
\hline \multirow[t]{2}{*}{$A_{09}$} & Initial & $54 \cdot 5$ & $68 \cdot 5$ & $76 \cdot 0$ & $253 \cdot 8$ & $24 \cdot 01$ \\
\hline & Change & 0 & +0.5 & $+1 \cdot 2$ & -0.3 & +0.22 \\
\hline \multirow{2}{*}{$\mathbf{A}_{10}$} & Initial & 51.5 & $75 \cdot 5$ & $84 \cdot 4$ & $246 \cdot 8$ & $25 \cdot 58$ \\
\hline & Change & $-1 \cdot 0$ & +0.5 & $-2 \cdot 6$ & +0.2 & -0.5 \\
\hline \multirow{2}{*}{$\mathrm{D}_{01}$} & Initial & 63.0 & $71 \cdot 5$ & $80 \cdot 7$ & $270 \cdot 0$ & $24 \cdot 91$ \\
\hline & Change & $-1 \cdot 0$ & $-2 \cdot 0$ & -7.5 & $-8 \cdot 2$ & -1.52 \\
\hline \multirow{2}{*}{$\mathrm{D}_{03}$} & Initial & $55 \cdot 0$ & $69 \cdot 5$ & $55 \cdot 8$ & $251 \cdot 6$ & $19 \cdot 49$ \\
\hline & Change & 0 & $-2 \cdot 0$ & +2.4 & +5.8 & +0.6 \\
\hline \multirow{2}{*}{$\mathrm{D}_{04}$} & Initial & $47 \cdot 5$ & 62.5 & 61.0 & 235.8 & $20 \cdot 77$ \\
\hline & Change & 0 & -1.0 & $-1 \cdot 2$ & -4.8 & -0.27 \\
\hline \multirow[t]{2}{*}{$\mathrm{D}_{05}$} & Initial & $59 \cdot 0$ & $69 \cdot 5$ & 51.6 & 253.8 & $18 \cdot 40$ \\
\hline & Change & 0 & 0 & 0 & -6.4 & 0 \\
\hline \multirow{2}{*}{$\mathrm{D}_{06}$} & Initial & $49 \cdot 0$ & $64 \cdot 5$ & 56.8 & $226 \cdot 0$ & $19 \cdot 75$ \\
\hline & Change & -0.5 & 0 & +4.4 & $+4 \cdot 4$ & +1.09 \\
\hline \multirow{2}{*}{$\mathrm{D}_{08}$} & Initial & $48 \cdot 0$ & $65 \cdot 5$ & $38 \cdot 8$ & $228 \cdot 2$ & $14 \cdot 27$ \\
\hline & Change & $+1 \cdot 0$ & -1.5 & -0.2 & $-5 \cdot 6$ & -0.08 \\
\hline \multirow[t]{2}{*}{$\mathrm{D}_{11}$} & Initial & $52 \cdot 5$ & $72 \cdot 0$ & $86 \cdot 4$ & $243 \cdot 2$ & 25.93 \\
\hline & Change & -0.5 & $-3 \cdot 5$ & $+2 \cdot 7$ & $+4 \cdot 4$ & +0.46 \\
\hline \multirow[t]{4}{*}{ Mean } & Initial & $52 \cdot 2$ & 67.96 & 65.68 & $242 \cdot 0$ & $21 \cdot 29$ \\
\hline & $(\mathrm{SD})$ & 6.1 & $5 \cdot 05$ & 18.85 & 16.0 & 4.57 \\
\hline & Change & -0.04 & -0.67 & $+0 \cdot 21$ & -0.5 & +0.05 \\
\hline & (SED) & 0.19 & $0 \cdot 45$ & 1.07 & $1 \cdot 4$ & $0 \cdot 19$ \\
\hline
\end{tabular}

* For details of subjects and diets, see Tables 1 and 2 and p. 440.

Table 4. Urinary nitrogen, creatinine and urea-nitrogen excretion in young Nigerian women given different levels of protein $\dagger$

(Values are means with their pooled standard deviations for twelve subjects over $5 \mathrm{~d}$ )

\begin{tabular}{|c|c|c|c|c|c|c|c|c|}
\hline \multirow{2}{*}{$\begin{array}{l}\text { Protein intake } \\
(\mathrm{g} / \mathrm{kg} \text { per } \mathrm{d})\end{array}$} & \multicolumn{2}{|c|}{$\begin{array}{c}\text { Urinary } N \\
(\mathrm{mg} / \mathrm{kg} \text { per } \mathrm{d})\end{array}$} & \multicolumn{2}{|c|}{$\begin{array}{c}\text { Creatinine } \\
(\mathrm{mg} / \mathrm{kg} \text { per } \mathrm{d})\end{array}$} & \multicolumn{2}{|c|}{$\begin{array}{c}\text { Urea N } \\
(\mathrm{mg} / \mathrm{kg} \text { per } \mathrm{d})\end{array}$} & \multicolumn{2}{|c|}{$\begin{array}{c}\text { Urea } N \\
\text { in urinary } N \\
(\%)\end{array}$} \\
\hline & Mean & $\mathrm{SD}$ & Mean & SD & Mean & SD & Mean & SD \\
\hline 0.3 & $41 \cdot 41$ & $4 \cdot 73$ & $18 \cdot 4$ & 0.39 & $22 \cdot 3$ & $3 \cdot 22$ & 53.8 & $3 \cdot 5$ \\
\hline 0.4 & $47 \cdot 0$ & 3.77 & $18 \cdot 8$ & 0.90 & $29 \cdot 4$ & $3 \cdot 20$ & 62.4 & 3.05 \\
\hline $0 \cdot 5$ & 53.6 & $5 \cdot 73$ & $19 \cdot 0$ & $0 \cdot 70$ & $36 \cdot 3$ & $4 \cdot 74$ & 67.6 & $2 \cdot 89$ \\
\hline 0.6 & $64 \cdot 9^{*}$ & $4 \cdot 45$ & $19 \cdot 2$ & $1 \cdot 0$ & $46 \cdot 6^{*}$ & $4 \cdot 40$ & $71 \cdot 8^{*}$ & $2 \cdot 48$ \\
\hline$F\left(\mathrm{df}_{3,33}\right)$ & \multicolumn{2}{|c|}{66.20} & \multicolumn{2}{|c|}{$2 \cdot 36$} & \multicolumn{2}{|c|}{$79 \cdot 3$} & \multicolumn{2}{|c|}{85.78} \\
\hline $\begin{array}{l}\text { Significance } \\
\text { of comparison }\end{array}$ & \multicolumn{2}{|c|}{$P<0.001$} & \multicolumn{2}{|c|}{$P>0.05$} & \multicolumn{2}{|c|}{$P<0.001$} & \multicolumn{2}{|c|}{$P<0.01$} \\
\hline
\end{tabular}

Mean values were significantly different from those at other levels of protein intake (two-way ANOVA); * $P<0.05$.

$\dagger$ For details of subjects and diets, see Tables 1 and 2 and p. 440 . 
Table 5. Nitrogen balance values $(m g N / k g$ per $d)$ in twelve young Nigerian women

\begin{tabular}{|c|c|c|c|c|c|c|c|c|}
\hline \multirow[b]{2}{*}{ Subject } & \multicolumn{4}{|c|}{$0.3 \mathrm{~g}$ protein $/ \mathrm{kg}$ per $\mathrm{d}$} & \multicolumn{4}{|c|}{$0.4 \mathrm{~g}$ protein $/ \mathrm{kg}$ per $\mathrm{d}$} \\
\hline & NI & UN & $\mathrm{FN}$ & NB & NI & UN & $\mathrm{FN}$ & NB \\
\hline$A_{04}$ & $62 \cdot 72$ & $42 \cdot 85$ & $20 \cdot 75$ & $-7 \cdot 83$ & $84 \cdot 46$ & $51 \cdot 32$ & $17 \cdot 60$ & +7.92 \\
\hline$A_{05}$ & 43.63 & $38-37$ & $15 \cdot 34$ & -1703 & $60 \cdot 55$ & $43 \cdot 26$ & $19 \cdot 67$ & $-10 \cdot 24$ \\
\hline$A_{08}^{00}$ & $51 \cdot 20$ & $46 \cdot 79$ & 12.92 & -15.46 & $68 \cdot 42$ & 51.98 & $12 \cdot 34$ & -3.82 \\
\hline$A_{09}$ & $46 \cdot 03$ & 36.82 & 18.39 & -16.13 & $63 \cdot 35$ & $47 \cdot 48$ & $19 \cdot 34$ & $-11 \cdot 33$ \\
\hline$A_{10}$ & $48 \cdot 72$ & $41 \cdot 80$ & 15.05 & -15.08 & $65 \cdot 79$ & $47 \cdot 30$ & $18 \cdot 37$ & $-7 \cdot 74$ \\
\hline $\mathrm{D}_{0 \mathrm{I}}$ & $40 \cdot 46$ & $39 \cdot 90$ & $11 \cdot 31$ & -17.69 & 55.62 & $42 \cdot 98$ & $12 \cdot 55$ & $-5 \cdot 76$ \\
\hline $\mathrm{D}_{03}$ & 46.03 & $35 \cdot 43$ & 14.08 & -10.43 & $61 \cdot 09$ & $42 \cdot 04$ & 14.98 & -3.79 \\
\hline $\mathrm{D}_{04}^{03}$ & $52 \cdot 82$ & $39 \cdot 66$ & 13.95 & -7.74 & $72 \cdot 02$ & 45.02 & $20 \cdot 82$ & -1.68 \\
\hline $\mathrm{D}_{05}$ & 43.63 & $62 \cdot 45$ & 14.82 & -30.59 & $58 \cdot 98$ & $48 \cdot 66$ & $20 \cdot 42$ & -19.96 \\
\hline$D_{06}^{00}$ & $49 \cdot 19$ & $39 \cdot 73$ & 17.61 & $-15 \cdot 10$ & $68 \cdot 42$ & $49 \cdot 16$ & 1301 & -2.79 \\
\hline $\mathrm{D}_{08}^{06}$ & $50 \cdot 18$ & $38 \cdot 50$ & $17 \cdot 14$ & -12.41 & $68 \cdot 42$ & $42 \cdot 40$ & $19 \cdot 51$ & $-1 \cdot 35$ \\
\hline $\mathrm{D}_{11}^{18}$ & $47 \cdot 34$ & $44 \cdot 65$ & 11.99 & $-16 \cdot 25$ & $64 \cdot 54$ & 52.05 & $10 \cdot 50$ & -5.87 \\
\hline Mean & $48 \cdot 50$ & $41 \cdot 41$ & $15 \cdot 30$ & -15.15 & 65.97 & 46.97 & 16.59 & $-5 \cdot 53$ \\
\hline \multirow[t]{2}{*}{ SD } & $5 \cdot 70$ & $4 \cdot 73$ & $2 \cdot 77$ & 5.95 & 7.47 & 3.77 & 3.68 & 6.71 \\
\hline & \multicolumn{4}{|c|}{$0.5 \mathrm{~g}$ protein $/ \mathrm{kg}$ per $\mathrm{d}$} & \multicolumn{4}{|c|}{$0.6 \mathrm{~g}$ protein $/ \mathrm{kg}$ per $\mathrm{d}$} \\
\hline Subject & NI & UN & $\mathrm{FN}$ & NB & NI & UN & FN & NB \\
\hline$A_{04}$ & $109 \cdot 0$ & $67 \cdot 20$ & $18 \cdot 70$ & +15.47 & $130 \cdot 72$ & 72.08 & $19 \cdot 18$ & $+30 \cdot 86$ \\
\hline$A_{05}$ & $77 \cdot 54$ & $48 \cdot 72$ & 18.64 & +2.03 & 93.37 & $57 \cdot 26$ & 17.93 & $\begin{array}{r}+9.58 \\
\end{array}$ \\
\hline$A_{08}$ & $86 \cdot 75$ & 57.08 & 13.98 & +7.54 & $106 \cdot 71$ & 63.84 & $14 \cdot 26$ & +20.01 \\
\hline$A_{09}$ & $81 \cdot 13$ & $51 \cdot 84$ & 20.08 & +1.06 & 97.74 & $62 \cdot 60$ & $20 \cdot 97$ & $+5 \cdot 27$ \\
\hline$A_{10}$ & 85.90 & $51 \cdot 58$ & 17.63 & +8.54 & $100 \cdot 55$ & $64 \cdot 34$ & 15.20 & $+12 \cdot 41$ \\
\hline$D_{01}$ & $71 \cdot 23$ & 52.04 & $10 \cdot 10$ & +0.94 & $81 \cdot 70$ & $59 \cdot 65$ & 11.90 & +1.55 \\
\hline $\mathrm{D}_{03}^{01}$ & $79 \cdot 65$ & $46 \cdot 16$ & $15 \cdot 22$ & $+10 \cdot 12$ & $95 \cdot 07$ & $68 \cdot 14$ & $16 \cdot 19$ & $+2 \cdot 14$ \\
\hline $\mathrm{D}_{04}$ & $92 \cdot 23$ & 53.78 & $20 \cdot 40$ & +9.91 & $110 \cdot 08$ & $70 \cdot 23$ & $17 \cdot 31$ & $+13 \cdot 94$ \\
\hline $\mathrm{D}_{05}^{04}$ & $74 \cdot 25$ & $52 \cdot 43$ & $13 \cdot 73$ & $+0 \cdot 22$ & $88 \cdot 62$ & 67.06 & $10 \cdot 44$ & +2.52 \\
\hline $\mathrm{D}_{06}^{05}$ & 87.62 & 55.88 & 14.79 & +8.80 & $106 \cdot 71$ & $65 \cdot 68$ & $17 \cdot 28$ & $+15 \cdot 16$ \\
\hline $\mathrm{D}_{0 \mathrm{~s}}$ & 87.62 & $47 \cdot 20$ & $22 \cdot 74$ & +6.53 & 108.93 & $60 \cdot 14$ & 22.06 & $+18 \cdot 13$ \\
\hline $\mathrm{D}_{11}$ & $81 \cdot 13$ & $58 \cdot 83$ & 11.55 & $+2 \cdot 60$ & 99.60 & $67 \cdot 46$ & $10 \cdot 50$ & +13.04 \\
\hline Mean & $84 \cdot 50$ & $53 \cdot 56$ & $16 \cdot 46$ & $+6 \cdot 15$ & $101 \cdot 55$ & $64 \cdot 87$ & $16 \cdot 10$ & +12.05 \\
\hline SD & 9.83 & 5.73 & 3.83 & $4 \cdot 76$ & $12 \cdot 51$ & $4 \cdot 45$ & 3.82 & $8 \cdot 63$ \\
\hline
\end{tabular}

NI, N intake; UN, total urinary $\mathrm{N}$ (mean of last $5 \mathrm{~d}$ ); FN, faecal $\mathrm{N} ; \mathrm{NB}, \mathrm{N}$ balance (assuming 5.45, 6.36, 6.56 and $7.1 \mathrm{mg} \mathrm{N} / \mathrm{kg}$ per $\mathrm{d}$ for sweat $\mathrm{N}$ for $0.3,0.4,0.5$ and $0.6 \mathrm{~g}$ protein $/ \mathrm{kg}$ per $\mathrm{d}$ respectively, and $1.5 \mathrm{mg} \mathrm{N} / \mathrm{kg}$ per $\mathrm{d}$ for menstrual loss).

showed a significant $\left(P<0.001, F_{3,33} 126.95\right)$ increase with increasing $\mathrm{N}$ intake. Increasing $\mathrm{N}$ intake improved the $\mathrm{N}$ balance by $32-78.5 \%$ for every $100 \mathrm{mg} \mathrm{N} / \mathrm{kg}$ rise in $\mathrm{N}$ intake (Table 6).

Individual regression analysis was used to calculate the maintenance $\mathrm{N}$ requirement (Table 6). The mean $\mathrm{N}$ requirement was 75.77 (SD 3.37) $\mathrm{mg} \mathrm{N} / \mathrm{kg}$ per d $(0.4 \mathrm{~g}$ protein $/ \mathrm{kg}$ per d). Estimates of allowances for individual variation to cover $97.5 \%$ population as $2 \mathrm{SD}$ or $25 \%$ of mean requirement was calculated as $95.0 \mathrm{mg} \mathrm{N} / \mathrm{kg}$ per $\mathrm{d}(0.6 \mathrm{~g}$ protein $/ \mathrm{kg}$ per d). When compared with the value obtained for young Nigerian men of $110.25(\mathrm{SD} 27.9) \mathrm{mg}$ $\mathrm{N} / \mathrm{kg}$ per $\mathrm{d}$, the difference in requirement was significant at $P<0.001(t 4.05$, df 25$)$. The mean $\mathrm{N}$ requirement expressed on a lean mass $(\%$ difference between body weight and body fat) basis was estimated at $122.8 \mathrm{mg} \mathrm{N} / \mathrm{kg}$ lean body weight per $\mathrm{d}(0.77 \mathrm{~g}$ protein $/ \mathrm{kg}$ lean body weight per $\mathrm{d}$ ) for the subjects. 
Table 6. Linear regression equations relating nitrogen balance to nitrogen intake for twelve young Nigerian women*

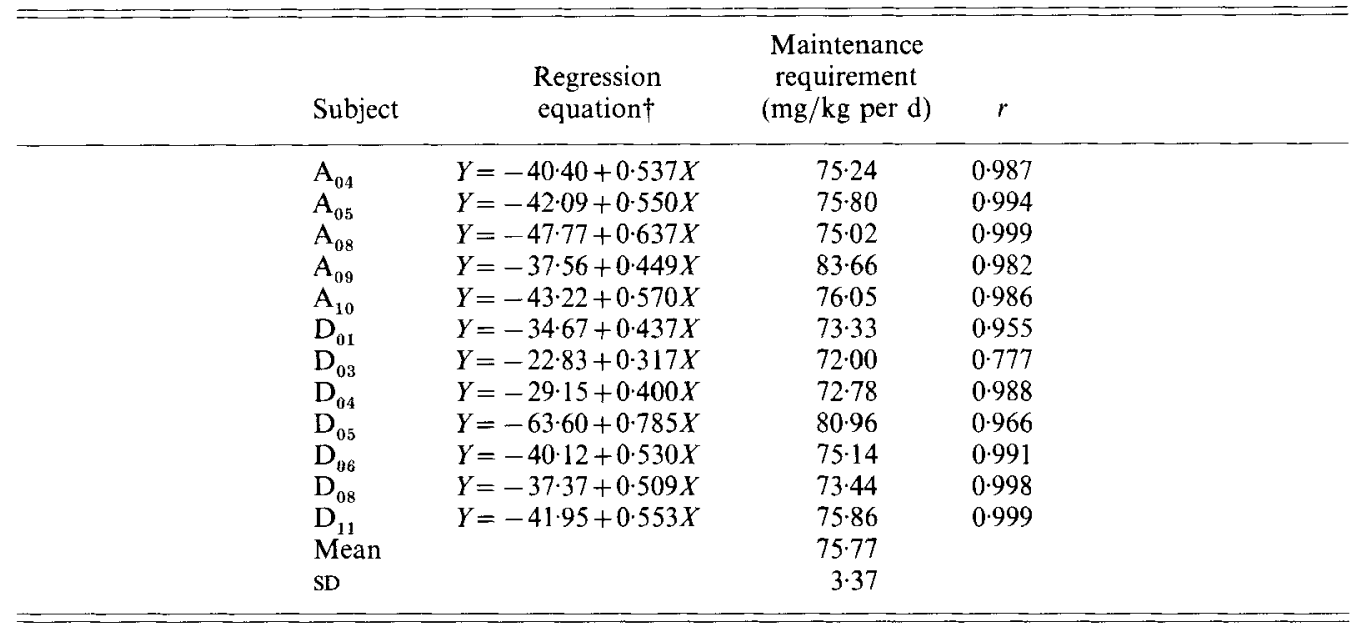

$Y, \mathrm{~N}$ balance ( $\mathrm{mg} / \mathrm{kg}$ per $\mathrm{d}) ; X, \mathrm{~N}$ intake $(\mathrm{mg} / \mathrm{kg}$ per $\mathrm{d})$.

* For details of subjects and diets, see Tables 1 and 2 and p. 440.

$\dagger$ Intercept $(Y=0)$ is $\mathrm{N}$ intake for the maintenance of $\mathrm{N}$ equilibrium.

Table 7. Biological value (BV), net protein utilization (NPC) and true and apparent digestibilities of the experimental diet at different levels of protein intake for young Nigerian woment

(Mean values and standard deviations for twelve subjects)

\begin{tabular}{|c|c|c|c|c|c|c|c|c|}
\hline \multirow{3}{*}{$\begin{array}{l}\text { Level of } \\
\text { protein intake } \\
(\mathrm{g} / \mathrm{kg} \text { per } \mathrm{d})\end{array}$} & & & & & \multicolumn{4}{|c|}{ Digestibility } \\
\hline & \multicolumn{2}{|c|}{ BV } & \multicolumn{2}{|c|}{ NPU } & \multicolumn{2}{|c|}{ Apparent } & \multicolumn{2}{|c|}{ True } \\
\hline & Mean & SD & Mean & SD & Mean & SD & Mean & so \\
\hline 0.3 & 0.57 & 0.055 & 0.56 & 0.054 & $68 \cdot 6$ & $9 \cdot 58$ & $99 \cdot 9$ & $5 \cdot 53$ \\
\hline 0.4 & 0.56 & 0.058 & 0.55 & 0.065 & $74 \cdot 7$ & $6 \cdot 01$ & 98.7 & 5.57 \\
\hline 0.5 & 0.55 & 0.028 & 0.54 & $0 \cdot 028$ & $80 \cdot 5$ & $4 \cdot 03$ & $98 \cdot 7$ & $4 \cdot 67$ \\
\hline 0.6 & $0.53^{*}$ & 0.039 & $0.52^{*}$ & 0.034 & $89 \cdot 2^{*}$ & $3 \cdot 27$ & $99 \cdot 3$ & 3.86 \\
\hline$F\left(\mathrm{df}_{3,33}\right)$ & \multicolumn{2}{|c|}{$2 \cdot 97$} & \multicolumn{2}{|c|}{2.94} & \multicolumn{2}{|c|}{$3 \cdot 21$} & \multicolumn{2}{|c|}{0.44} \\
\hline
\end{tabular}

Mean values were significantly different from those at other levels of protein intake (two-way ANOVA): * $P$ $<0.05$.

$\dagger$ For details of subjects and diets, see Tables 1 and 2 and p. 440 .

\section{Protein utilization and digestibility}

The BV, NPU and the true and apparent digestibilities for the habitual diet at different $\mathrm{N}$ intake levels in the young women studied are presented in Table 7 . Obligatory $\mathrm{N}$ loses were calculated from the mean of individual regression equations relating $\mathrm{N}$ intake (NI) to urinary (UNE), faecal (FNE) and sweat (SNE) $N$ losses.

and

$$
\begin{aligned}
& \mathrm{UNE}=20 \cdot 62+0 \cdot 414 \mathrm{NI}, \\
& \mathrm{FNE}=15 \cdot 18+0 \cdot 011 \mathrm{NI}, \\
& \mathrm{SNE}=4 \cdot 12+0.03 \mathrm{NI} .
\end{aligned}
$$


Thus, the obligatory $\mathrm{N}$ losses for urine, faeces and sweat were $20 \cdot 62,15 \cdot 18$ and $4 \cdot 12 \mathrm{mg}$ $\mathrm{N} / \mathrm{kg}$ per $\mathrm{d}$ respectively. The BV and NPU were significantly reduced $(P<0.05)$ with increase in protein intake. The apparent digestibility of the experimental diet increased significantly $(P<0.05)$ with increasing protein intake but the true digestibility did not change with changing level of protein intake.

\section{DISCUSSION}

In the report of FAO/WHO/UNU (1985) there was insufficient data to justify setting a different allowance for adult females. The data considered were those of caucasians in privileged countries (Bodwell et al. 1979; Calloway \& Kurzer, 1982). Since the variation in protein requirement is the result of the modifying effect of environment on the expression of that potential, it is, therefore, necessary to determine what the appropriate estimates are for protein among women for various populations. Thus, there was a need to obtain such data for Nigeria with her populations living under conditions prevailing in developing countries and consuming diets differing in characteristics. Our subjects were homogeneous in their living arrangements and academic activities. The choice of university women was mainly to compare our results with those of our earlier study on young men (Atinmo et al. $1988 \mathrm{~b}$ ). Our young women had a constant level of energy intake which was judged adequate at $0.18 \mathrm{MJ} / \mathrm{kg}$ per $\mathrm{d}$ for the short period of $11 \mathrm{~d}$ studied, as there were no significant changes in body anthropometric measurements such as total skinfold thickness, waist circumferences, mid-arm circumference and percentage body fat.

The $\mathrm{N}$ loss in urine was observed to increase linearly with increases in protein intake as observed by many workers in this area (Young \& Scrimshaw, 1968; Calloway \& Margen, 1971). The increases observed in total urinary $N$ with increased protein intake were attributed largely to increases in urea $N$ excretion. The percentage of the urinary $N$ that was made up of urea varied from 54 with the lowest protein intake to 72 with the highest protein intake.

Daily urinary creatinine in our subjects did not fluctuate with changing levels of protein intake. Although urinary creatinine was used to monitor the completeness of urine collection, it can also be used to determine the muscle mass of subjects (Chinn, 1967). Similar results were obtained by other workers (Young et al. 1973; Huang \& Lin, 1982) with different levels of protein intake derived from egg protein and customary diets respectively.

Our extrapolated obligatory total $\mathrm{N}$ loss was about $40 \mathrm{mg} \mathrm{N} / \mathrm{kg}$ per $\mathrm{d}$ for the habitual diets. This value is much less than the estimated obligatory losses obtained for our men (Atinmo et al. 1985). However, the value was close to the actually determined losses reported by Bodwell et al. (1979) and Scrimshaw et al. (1976) for young and elderly women.

Individual regression analysis relating $\mathrm{N}$ intake to $\mathrm{N}$ balance in the present study gave a mean daily protein requirement for the habitual diet of $0.47 \mathrm{~g}$ protein $/ \mathrm{kg}$ per d. To derive the safe level of protein intake from the mean requirement, an allowance covering individual variation has to be estimated. Mean requirement plus $2 \mathrm{SD}$ is usually considered to be able to satisfy the need for nearly all $(97.5 \%)$ the population $(0.6 \mathrm{~g}$ protein $/ \mathrm{kg}$ per d). Our result, however, is similar to the results obtained by Calloway \& Kurzer (1982) with egg-white protein and by Hussein (1984) for Egyptian women on their customary diet (73 and $77.4 \mathrm{mg} \mathrm{N} / \mathrm{kg}$ per $\mathrm{d}$ respectively). However, the value for Indian women (Pasricha et al. 1965) was $94.0 \mathrm{mg} \mathrm{N} / \mathrm{kg}$ per d.

When we compared our findings on a per $\mathrm{kg}$ body-weight basis with those of our previous study on young men we found that the requirements differed significantly. Our young men had a mean requirement of $110 \mathrm{mg} \mathrm{N} / \mathrm{kg}$ per $\mathrm{d}$. However, we observed a similar 
slope in the data for both sexes indicating similar utilization of protein. The major difference was in the obligatory $\mathrm{N}$ loss. This may be due to differences in the body composition of both groups. When $\mathrm{N}$ requirement was expressed on lean body mass basis the values obtained for our female subjects of $122.8 \mathrm{mg} \mathrm{N} / \mathrm{kg}$ lean body weight per $\mathrm{d}$ was similar to the $130.3 \mathrm{mg} \mathrm{N} / \mathrm{kg}$ lean body weight per $\mathrm{d}$ obtained for our male subjects. Thus, the difference in protein requirement between the sexes may be attributed in part to the fact that lean body mass of our female subjects is only about $70 \%$ of the value for our male subjects. However, the influence of hormonal regulation on $\mathrm{N}$ balance cannot be overlooked as a possible factor for the difference observed (Calloway \& Kurzer, 1982).

The NPU value of 0.55 obtained for the habitual diet is similar to the NPU value obtained in our earlier study (Atinmo et al. 1988b) for young men on a similar diet. This is comparable also with the results of Japanese young men $(0.50-0.55$; Kishi et al. 1978) and Chinese men (0.55-0.58; Huang \& Lin, 1982) on their mixed customary diet.

Thus, we observe a good utilization of the dietary protein by our subjects. We can assume, therefore, that, for a habitual diet containing mixed dietary proteins, there could be a complementary pattern of amino acids, so that specific essential amino acid deficiency is unlikely to occur in adults at adequate protein intake. Thus, utilization of the protein would be expected to compare favourably with standard reference proteins like eggs. We observed significant and obvious reductions in the BV and NPU values at the highest protein intake as in our young men. This is an indication of reduced utilization of protein at higher protein intakes. Studies of Calloway \& Margen (1971) and Inoue et al. (1973) also found that the utilization of egg protein in adult subjects was consistently lower at levels above that just sufficient to maintain balance.

Although a longer-term $\mathrm{N}$ balance study is needed to confirm our findings in terms of protein requirement, it might be advisable at this stage that the requirements for women be given more attention by the future Expert Consultative Committees.

The authors hereby acknowledge the support of the United Nations University and University of Ibadan Research Grants for providing the grants for this study; the advice and critical evaluation of the manuscript by Professor D. H. Calloway; and the full cooperation of the subjects.

\section{REFERENCES}

Atinmo, T., Egun, G. \& Mbofung, C. M. F. (1988a). Long-term evaluation of the adequacy of habitual diets to provide protein needs of adult Nigerian men. British Journal of Nutrition 60, 459-466.

Atinmo, T., Mbofung, C. M. F., Egun, G. \& Osotimehin, B. (1988 b). Nitrogen balance study in young Nigerian adult males using four levels of protein intake. British Journal of Nutrition 60, 451-458.

Atinmo, T., Mbofung, C. M. F., Hussain, M. A. \& Osotimehin, B. (1985). Obligatory nitrogen losses in Nigerian men. British Journal of Nutrition 54, 605-611.

Bodwell, C. E., Schuster, E. M., Kule, E., Brooks, B., Womack, M., Steele, P. \& Ahrens, R. (1979). Obligatory urinary and faecal nitrogen losses in young women, older men and young men and the factorial estimation of adult protein requirements. American Journal of Clinical Nutrition 32, 2450-2459.

Bonsnes, P. W. \& Taussky, H. H. (1945). On the calorimetric determination of creatinine by the Jaffe reaction. Journal of Biological Chemistry 158, 581-591.

Calloway, D. H. \& Kurzer, M. S. (1982). Menstrual cycle and protein requirements of women. Journal of Nutrition 112, $336-366$

Calloway, D. H. \& Margen, S. (1971). Variations in endogenous nitrogen excretion utilization as determinants of human protein requirements. Journal of Nutrition 101, 205-216.

Chinn, K. S. K. (1967). Prediction of muscle and remaining tissue protein in man. Journal of Applied Physiology 23, 713-715.

Food and Agriculture Organization/World Health Organization (1973). Energy and protein requirements. Report of a Joint FAO/WHO ad hoc Expert Committee. Technical Report Series no. 522. Geneva: WHO.

Food and Agriculture Organization/World Health Organization/United Nations University (1985). Energy and Protein Requirements. Report of Joint Expert Consultation. WHO Technical Report Series no. 724. Geneva: WHO. 
Huang, P. C. \& Lin, C. P. (1982). Protein requirements of young Chinese male adults on ordinary Chinese mixed diet and egg diet at ordinary levels of energy intake. Journal of Nutrition 112, 897-907.

Hussein, M. A. (1984). Protein requirement of Egyptian women. In Protein-Energy Requirement Studies in Developing Countries: Results of International Research. United Nations University Food and Nutrition Bulletin Supplement no. 10, pp. 102-106 [W. M. Rand, R. Uuay, and N. S. Scrimshaw, editors]. Tokyo: United Nations University.

Inoue, G., Fujita, J. \& Niiyama, Y. (1973). Studies on protein requirements of young men fed egg protein and rice protein excess and maintenance energy intakes. Journal of Nutrition 103, 1673-1687.

Kishi, K., Miyatani, S. \& Inoue, G. (1978). Requirement and utilization of egg protein by Japanese young men with marginal intakes of energy. Journal of Nutrition 108, 658-669.

Millward, D. J., Jackson, A. A., Price, G. \& Rivers, J. P. W. (1989). Human amino acid and protein requirements: current dilemmas and uncertainties. Nutrition Research Reviews 2, 109-132.

Munro, H. N. (1985). Historical perspective on protein requirements: Objectives for the future. In Nutritional Adaptation in Man, pp. 155-168 [K. Blaxter and J. C. Waterlow, editors]. London and Paris: John Libbey.

Munro, H. N. \& Fleck, A. (1969). Analysis of urine and body fluids for nitrogenous constituents. In Mammalian Protein Metabolism, pp. 423-525 [H. N. Munro, editor]. New York: Academic Press.

Pasricha, S., Rao, N., Mohanram, K. \& Gopalan, C. (1965). Nitrogen balance studies of Women in India. Journal of the American Dietetic Association 47, 269-273.

Rand, W. M., Scrimshaw, N. S. \& Young, V. R. (1977). Determination of protein allowance in human adults from nitrogen balance data. American Journal of Clinical Nutrition 30, 1129-1134.

Scrimshaw, N. S., Perera, W. D. \& Young, V. R. (1976). Protein requirements of man: Obligatory urinary and faecal nitrogen losses in elderly women. Journal of Nutrition 106, 665-670.

Sirbu, E. R., Margen, S. \& Calloway, D. H. (1967). Effect of reduced protein intakes on nitrogen loss from the human integument. American Journal of Clinical Nutrition 20, 1158-1165.

Spence, N. P., Abernathy, R. P. \& Ritchey, S. J. (1972). Excretion of nitrogen in sweat by preadolescent girls consuming low protein diets. American Journal of Clinical Nutrition 25, 275-278.

United Nations University World Hunger Programme (1979). Protein-energy Requirements Under Conditions Prevailing in Developing Countries: Current Knowledge and Research Needs. Tokyo: The United Nations University.

Wybenga, D. R., Giorgio, J. D. \& Pileggi, V. I. (1971). Manual and automated methods for urea nitrogen measurement in whole serum. Clinical Chemistry 17, 891-895.

Young, V. R. \& Scrimshaw, N. S. (1968). Endogenous nitrogen metabolism and plasma amino acids in young adults given a 'protein-free' diet. British Journal of Nutrition 22, 9-20.

Young, V. R., Taylor, Y. S. M., Rand, W. M. \& Scrimshaw, N. S. (1973). Protein requirements of man: Efficiency of egg protein utilization at maintenance and submaintenance levels in young men. Journal of Nutrition 103, $1164-1174$. 